\title{
Identidad étnica y género entre adolescentes de origen marroquí
}

\author{
Sonia Veredas Muñoz \\ Universidad Carlos III de Madrid. \\ sveredas@usal.es
}

Recibido: 30-03-2008

Aceptado: 01-07-2008

\section{Resumen}

En este artículo, sistematizamos algunos de los factores que condicionan el proceso de construcción de la identidad étnica entre los jóvenes inmigrantes marroquíes en España, especialmente las condiciones en que la identidad étnica puede activarse como recurso individual en la sociedad receptora para afirmar y mantener la autoestima y la aceptación del endogrupo y luchar contra el racismo y la discriminación. Estos factores incluyen los "otros» grupos de referencia para el individuo, el efecto del islam y la voluntad de preservación cultural entre los padres, factores cuya influencia en nuestro tema objeto de estudio ha de considerarse conjuntamente.

Palabras clave: identidad étnica; jóvenes marroquíes.

Abstract. Ethnic identity and gender among teenagers of Morrocan origin

In this article we systematize some factors conditioning the ethnic identity construction of young Moroccans immigrants in Spain, specifically the conditions under which ethnicity can be activated as an individual resource in the receptor society for affirming and maintaining self-esteem, fighting against racism and discrimination, or gaining acceptance as an ethnic group. The mentioned factors are grouped in various headlines - the «others» groups of reference, the effect of Islamic religion and the parental efforts to preserve the cultural heritance on their children-, although their effect upon our study subject is not independent of the rest of them.

Key words: ethnic identity; Moroccans adolescence.

\section{Sumario}

1. Objetivo y marco teórico del trabajo

2. Identificación de los «otros» grupos de referencia significativos

3. Respuestas identitarias entre los marroquíes
4. ¿Identificaciones diferentes según género?

5. Conclusión

6. Referencias bibliográficas 


\section{Objetivo y marco teórico del trabajo}

En este trabajo, me propongo examinar: 1) si es posible afirmar el desarrollo de una identidad étnica entre estos jóvenes, y 2) si el desarrollo de la misma y su contenido concreto guardan relación con el género. La orientación de este artículo es principalmente exploratoria y descriptiva: se trata, en primer lugar, de clarificar las opciones identitarias - que más bien han de ser contempladas como tipos ideales - de los adolescentes de origen marroquí y de fundamentarlas en el análisis de su discurso, discurso parcialmente recogido aquí de modo que el lector pueda supervisar el proceso inductivo seguido por la autora. Se verá que estos materiales sugieren diversas líneas de interpretación, algunas aquí tratadas, pero nos parece ya que cada una de ellas precisaría mayor profundización.

Antes de abordar esta empresa, creo oportuno realizar algunas apreciaciones orientadas a definir con mayor precisión nuestro objeto de estudio y la perspectiva desde la que aquí es tratado. Hablamos, en efecto, de identidad étnica entre adolescentes de origen marroquí: ¿por qué no hablar de identidad, sin más?, :por qué hablar exclusivamente de «identidad étnica» y no de cualquier otra dimensión identitaria o de todas las posibles?, ‘acaso se corre el riesgo de convertir lo étnico en elemento distintivo y potencialmente distanciador y hasta problemático para la convivencia?

Junto a estas preguntas, al comenzar el análisis de los procesos de construcción de identidad entre los adolescentes de origen marroquí, se me plantearon otras: ¿qué es identidad?, ¿qué es identidad étnica?, ¿qué tiene de distintivo la edad adolescente en lo referido a identidad?, ¿cómo rastrear lo identitario en los discursos individuales?, ¿qué añade — si añade algo — la condición de extranjero o hijo de extranjero a los procesos de construcción de identidad?, ¿qué añade ser marroquí o de origen marroquí? No podemos abordar aquí todas estas cuestiones con detalle, pero es sabido que el estudio de la identidad, de la identidad étnica, de la adolescencia como fase en el proceso de construcción identitaria, etc., en nuestros días, es profuso y fructífero. $\mathrm{Me}$ limitaré, pues, a aportar algunas de las ideas que soportan nuestro estudio.

Sobre el significado de la identidad o sentido del yo, sabemos que es resultado de un proceso que es social, por cuanto los materiales de los que emana son sociales, independientemente de que la idiosincrasia individual lleve a conjugarlos de un modo u otro. El contexto social ofrece los ingredientes a partir de los cuales se verificará el proceso de construcción identitaria (hablamos, pues, de "construcción» individual, pero socialmente constreñida) ${ }^{1}$. En segun-

1. Para Erikson (1980: 19): «La formación de la identidad utiliza un proceso de reflexión y observación simultáneas, un proceso que tiene lugar en todos los niveles del funcionamiento mental y por medio del cual el individuo se juzga a sí mismo a la luz de lo que advierte, como el modo en que otros le juzgan a él en comparación consigo mismo y con respecto a una tipología significativa para ellos, mientras que él juzga su modo de juzgarle a él con arreglo a cómo se percibe a sí mismo en comparación con ellos y a los tipos que han llegado a tener importancia para él». 
do lugar, la identidad es, en parte, proceso de diferenciación, su condición es inseparable de la «alteridad». Como afirma Aranguren (1993): «El otro está en el origen de mi yo", de modo que el examen del contenido de aquel nos remite a la relación entre el individuo y su entorno, y obliga a entenderlo desde una visión dialéctica. Así, la identidad se define como un doble proceso de diferenciación e igualación, y ambas dimensiones se remiten al contexto social del individuo, de modo que «son [...] las identidades de esos otros y el marco social de referencia los que marcan las cuestiones respecto de las que tiene sentido igualarse y diferenciarse: por tanto, tematizan la identidad personal» (Revilla, 1998: 19). Finalmente, la estructura multidimensional de las identidades (donde el referente puede ser la nación, la religión, la lengua, la raza, etc.) se manifiesta en el «difícil equilibrio de esas identificaciones alternativas y/o complementarias [que] debe ser construido cotidianamente en función de los contextos de acción, de las circunstancias, de las situaciones, de los talantes, de los interlocutores» (Lamo de Espinosa, 1995: 26). Ello obliga a considerar la serie de «otros» identificados por la población objeto de estudio y se manifiesta en sucesivas y diferentes identificaciones en función del «otro» que se encare: «negociación situacional de las identidades» (Nanda, 1987).

En cuanto a qué significa «identidad étnica», asumimos aquí la definición de Smith (1991: 182), según la cual una persona se considera «miembro del grupo étnico en cuanto admite a un grupo predominante de referencia, cuyos puntos de vista o perspectivas sirven para establecer las metas personales, regular la propia conducta, desarrollar lazos emocionales y simbólicos con el grupo, así como proximidad psicológica». Es decir, la afirmación de identidad étnica implica la detección de un considerable peso relativo del grupo étnico de referencia en cuanto a los valores, los puntos de vista y la autopercepción del entrevistado. Phinney (1991) aporta una definición más operativa del concepto, del que ofrece varios indicadores: autoidentificación, actitudes hacia el propio grupo étnico, actitud hacia uno mismo como miembro del grupo étnico (conocimiento pasivo versus conocimiento activo de la propia cultura), conductas y prácticas étnicas, afirmación y orgullo de pertenencia. La mayor o menor intensidad de la presencia de estos rasgos permite concluir identidad étnica «fuerte» o "débil». El mismo Phinney reconoce que tales indicadores no siempre correlacionan con fuerza y nuestras observaciones permiten, en este sentido, señalar algunos matices: en primer lugar, la identidad étnica "fuerte» no significa siempre identificación acrítica con el grupo de origen: hemos comprobado que los discursos más críticos con el endogrupo resultan a menudo de un mayor conocimiento relativo del mismo, de más curiosidad e indagación sobre sus pautas culturales y comparación con las de otros grupos. En tales construcciones identitarias, coexisten una indudable autoidentificación como miembro del grupo étnico y la citada capacidad de distanciamiento crítico: digamos que, «en lo bueno y en lo malo», uno se define marroquí. Por otra parte, tampoco existe una clara correlación entre identidad étnica y conductas y prácticas étnicas, y esto es particularmente cierto entre los varones, como veremos. Una cosa es indudable: la norma entre 
nuestros entrevistados es la afirmación segura y generalmente orgullosa de la propia identidad marroquí.

Si el proceso de aculturación significa distanciamiento o desasimiento del propio grupo étnico como referencia moral y afectiva privilegiada, origen de la propia cosmovisión y de los propios patrones morales - o, en grado más leve, el abandono de usos y costumbres propios de la cultura de origen-, no consideramos que esto pueda predicarse de nuestra población objeto de estudio. Ciertamente, el cambio de entorno fuerza inevitablemente el de algunas costumbres, inviables en el nuevo. Además, hemos encontrado — con escasa frecuencia relativa - narraciones en que se rastrea algo que intuimos cercano a la actitud "cosmopolita» que refiere Giddens (2000): en tales casos, el adolescente refiere y enjuicia desde una posición en que es capaz de entender mejor a todos, pero se enfrenta a cierto riesgo de marginación entre sus compatriotas, aunque afronta mejor que muchos el de anomia porque ha luchado más para definir su universo moral. Sin embargo, hablar en tales casos de «aculturación» es muy arriesgado, porque en el juicio subyace una visión casi esencialista de la cultura, inamovible, única, y parece claro que en Marruecos hay muchos Marruecos y que "lo marroquí» es variado y cambiante. Por tanto, nos limitamos a rastrear la identidad en lo que uno dice de sí mismo, directa o indirectamente, en el relato de su vida, de su trato con los demás. Interesa aquí, sobre todo, la autoidentificación y el ámbito de relaciones interpersonales: si uno se relaciona sobre todo o con más intimidad con marroquíes y, además, da a entender - aún indirectamente-, de modo reiterado, convencido y orgulloso, que se siente marroquí, asumimos que tiene «identidad étnica fuerte». Esto es lo «esencial» aquí. Por lo demás, la identidad étnica es también situacional, y las identificaciones, alternantes: el «nosotros» de un momento del discurso deviene con frecuencia «ellos» en otro momento: situación y no esencia.

La provisionalidad que predicamos de las construcciones identitarias aquí referidas no solo deriva de su definición situacional, sino también del momento vital a que se refieren: la adolescencia. Erikson (1980) ha analizado de manera profunda esta etapa vital, que caracteriza como de crisis, proceso definitivo en la construcción de la identidad personal. No vamos a detenernos en su análisis, que solo podríamos empeorar, pero sí a recordar que se trata de una etapa confusa en todo caso: no es fácil definir quien es uno y qué camino ha de seguir, particularmente en sociedades como las modernas, donde la aparente panoplia de opciones vitales y libertad de elección dificultan mucho la tarea. Es aquí donde parece clara la relevancia de la condición de extranjero (o hijo de) en el análisis de los procesos de construcción de identidad y también, como veremos más adelante, se manifiesta el significado de ser marroquí o hijo de marroquí. Efectivamente, los materiales culturales de referencia que se ofrecen a nuestros adolescentes son, en ocasiones - en tanto hijos de marroquíes que viven en España-, difíciles de conjugar y a veces exigen compromisos incompatibles que cada uno sortea como puede. El proceso de reflexión psicosocial que acompaña al proceso de construcción identitaria se revela, entre estos jóvenes, de manera especialmente clara. Tanto es así que, en ocasiones, las entrevistas pare- 
cen monólogos, vertido viva voce de un intenso diálogo interior que precedía evidentemente a mis demandas como entrevistadora. Casi siempre me ha parecido clara, como digo, la búsqueda identitaria en estos jóvenes, que entre los mayores parece resuelta en mayor medida. En otros casos, sin embargo, el conflicto y la confusión son evidentes — sobre todo en chicos: más retraimiento, apatía, agresividad - y a veces también lo que Erikson (1980) denomina «exclusión» - crisis solventada con la asunción acrítica de los planes de otras personas, en este caso, los padres, práctica más frecuente entre las chicas 2 -

Finalmente, ¿cómo rastrear lo identitario en lo discursivo? McAdams (1989) ha reflexionado sobre el desarrollo de la identidad narrativa. Dicho autor recuerda que, para Erikson, el desarrollo de la identidad está estrechamente ligado al relato de una narración coherente sobre uno mismo, un relato con argumento y puesta en escena, con sentido de unidad y propósito. Al analizar la aportación de Erikson, McAdams afirma el carácter ideológico de la construcción identitaria entre adolescentes ${ }^{3}$. Así, el marco ideológico desde el que se dota de sentido a la vivencia y al sentir individual condiciona la selección de escenas — «episodios nucleares», según McAdams - relatadas y otorga en ocasiones a la narración - y esto se percibe sobre todo en las entrevistas a los más jóvenes - cierto carácter irreal, de fábula, que solo la experiencia y la madurez mitigan. Y entonces los relatos se reformulan dando más entrada a lo imperativo social: así se percibe en el análisis de las entrevistas realizadas. Es decir, es claro que la condición adolescente tiene un trasunto "particular» en lo narrativo, y ese carácter ideológico que a veces adquiere matices de fábula, más expresión del querer ser que del ser real, se ha evidenciado en nuestro trabajo de campo: el tono peculiar e individualísimo, la congruencia más o menos esforzada y casi siempre traicionada por significativos comentarios... En definitiva, no decimos nada que no haya sido dicho, pero conforta verificar en nuestra investigación lo que algunos estudiosos han anticipado y sistematizado de modo admirable.

2. Terrén (2007) analiza la peculiaridad del proceso de construcción identitaria entre los jóvenes de origen extranjero, asociada al efecto estigmatizante de las representaciones mediáticas y de su nominación política como «jóvenes inmigrantes» — hayan emigrado o no- - a la tensión entre "aquí y allí» que marca su vivencia cotidiana y al significado que en este caso tiene la etapa de adolescencia. Al respecto, el autor recuerda la "particularidad histórica de esta categoría de edad, que otras culturas desconocen o valoran de manera diferente», y ello en relación con aspectos tales como el nivel de autonomía personal, la relación con personas de otro sexo o los hitos de acceso a la edad adulta.

3. «El chico o la chica en la antesala de la adolescencia ya ha formado sus preferencias conscientes e inconscientes y las inclinaciones con respecto a la narración de aspectos tales como: el tono, la imagen y el tema. Ahora el niño está listo para comenzar el trabajo de formular todo un marco para su propia historia de vida. El marco es ideológico [...] Erikson considera la formación de una ideología coherente como un prerrequisito para la formación de una identidad. La mente adolescente es una mente esencialmente ideológica; es la mirada ideológica de la sociedad que habla más claramente al adolescente que está ilusionado de ser afirmado por sus semejantes y está listo para ser confirmado a través de credos y programas que al mismo tiempo le definen lo que es malo, misterioso o inexplicable y perjudicial (Erikson, 1963: 263)» (McAdams, 1989: 166). 


\section{Identificación de los «otros» grupos de referencia significativos}

Tras estas apreciaciones preliminares, expongo algunas de las conclusiones derivadas del trabajo que he desarrollado dentro del proyecto de investigación Identidades en construcción (SEJ2004-02006/SOCI). El trabajo de campo generó cerca de 120 entrevistas en profundidad con adolescentes (jóvenes de catorce a veinte años) de origen extranjero residentes en España y decidí centrar mi análisis en los procesos de construcción de identidad referidos a los de origen marroquí —nacidos aquí o reagrupados-. Para responder a las cuestiones inicialmente planteadas, profundizaremos en dos aspectos, el primero de ellos relativo a la identificación de los «otros" grupos de referencia significativos para los marroquíes, «otros» respecto a los cuales su autopercepción se construye y/o se reconstruye. En segundo lugar, perfilaremos las principales modalidades identificatorias detectadas. Finalmente, intentaremos justificar la hipótesis que aquí avanzamos: la existencia de diferencias de género en cuanto a las formas de (re)construcción de identidad, diferencias relacionadas con el mayor control relativo ejercido sobre las mujeres por parte de la familia y el islam. El resultado de este mayor control relativo sobre las féminas es el refuerzo de la conciencia étnica en ellas y el acortamiento del nivel de autonomía personal, reducción que significa también salvaguarda frente a la anomia; paralelamente, el menor grado de control sobre los hijos varones los expone en mayor medida al riesgo de anomia, lo cual, en términos de identidad étnica, significa menor grado de ajuste a las conductas propias de endogrupo, pero no menor intensidad en su autoidentificación como marroquíes.

Dicho esto, vamos a identificar a los «otros» más significativos entre los adolescentes de origen marroquí. Hemos de advertir, empero, que las identificaciones grupales son etiquetas asignadas a «otros» colectivos y que los juicios o prejuicios grupales pueden coexistir con relaciones cercanas a nivel individual. Estos «otros» se rastrean en el discurso de los entrevistados porque son afirmados explícitamente como tales o a veces indirectamente, es decir, invocados como lo que uno no es ni quiere ser.

1) Compatriotas que dan mala imagen del grupo (venden droga y/o la consumen, cometen delitos, particularmente hurtos) debido a conductas desviadas. Son un "otro" no recomendable, que refuerza un estigma que pesa cotidianamente sobre el grupo. Un «otro», además, con particular eco en los medios de comunicación ${ }^{4}$.

2) Compatriotas coetáneos no practicantes. El concepto de "práctica» religiosa que se maneja por lo general es estrictamente ritualista, de modo que, aunque la dimensión ética del islam no es desconocida, no se juzga

4. "[...] y yo digo que soy marroquí, pero muchas veces digo: "Yo soy..., no sé qué" [otra nacionalidad], porque la gente empieza a decir: "Los moros, no me voy con él porque me roba o es esto". Y yo normalmente digo: "Yo he nacido aquî", ¿entiendes?, y ya la gente se baja la mano» (E9). 
desde ella al correligionario. El rechazo al no practicante se proyecta con preferencia sobre las mujeres: se transige con el varón que fuma, va a discotecas o tiene escarceos sexuales con chicas, pero no es permisible lo mismo en ellas, quienes, además, son portadoras de esta visión y generalmente no la cuestionan.

La ausencia de práctica religiosa suele explicarse en razón del desconocimiento, y los padres siempre son responsabilizados por ello. Sobre este particular, no suele aceptarse «mestizaje» alguno: un hijo de musulmán o musulmana ha de ser musulmán y para ello convenientemente adoctrinado. El islam no es negociable, es «la» verdad, y quien no accede a ella es, sobre todo si se trata de mujeres, digno de lástima o de reprobación.

3) Musulmanes integristas: resulta esencial para casi todos los entrevistados que no se asimile «marroquí» o «musulmán» a "terrorista». El estigma generalizado - particularmente gravoso para los musulmanes que viven en la UEque arriesga la conducta de los terroristas explica el interés de muchos de nuestros informantes en dar cuenta de la verdadera esencia del islam, de su fundamento pacífico, y también de su cercanía al cristianismo: se busca generar proximidad — como estrategia de autolegitimación a veces y otras como llamada de atención frente a la cosificación de la diferencia ${ }^{5}$ - allí donde los correligionarios extremistas marcan distancia.

Si la mayoría de los «otros» que referimos existen como referentes próximos en la vida cotidiana de los entrevistados, la presencia de los musulmanes integristas es menor, aunque los chicos conocen, por lo general, paisanos pertenecientes a familias con una visión extremista del islam y que emiten afirmaciones escandalosas, próximas a las argumentaciones fanáticas ${ }^{6}$. Pero este «otro» es también el de los medios de comunicación, voceros y/o inductores de una percepción de lo marroquí y lo musulmán que los chicos incorporan como algo de lo que distanciarse.

4) Marroquíes rifeños: los entrevistados no suelen identificar la diferencia étnica, de modo que la dualidad formada por árabe y rifeño — que es, en rea-

5. «Yo muchas veces, en el segundo de la ESO, por ejemplo, el libro te pone "Y hay que rezar a Alá y tal y cual y tal”. Di "Dios", que es lo mismo [...] o sea, Jesús es un profeta nuestro; o sea, cuando rezamos, siempre al terminar se la dedicamos a tó los profetas, o sea, también a Jesús, a Mahoma, a todos ¿entiendes? No solo es a "Alá, Alá, Alá". O sea, que los libros de historia tenían que ponerlos más... Es que, no sé, más iguales, ¿entiendes? O sea, que son casi las mismas religiones, o sea, es el mismo Dios, el mismo significado y todo, solo que vosotros tenéis a Jesús y nosotros tenemos a Mahoma y ya está. Eso es la única diferencia» (E3).

«La gente que han hecho las bombas y eso, ellos dicen que son musulmanes, pero no son musulmanes porque tú te lees el Corán y no pone eso" (E8).

6. «Pues le pregunté, dije: "Mira lo que está pasando, que, que mira lo que está pasando esa pobre gente" [a propósito del 11-M], y me dice: "Se lo tienen merecido". "Mira porque -me dice- porque Dios se lo ha hecho por no ser musulmanes". Y vas y dices: " $\mathrm{i} J$ doder, coño, que yo estoy viviendo con españoles! Conozco de tó: cristianos, judíos, hasta conozco un hindú por ahí, ¿entiendes?” [...] ellos no se dan cuenta de lo que hacen, ellos, ellos dicen lo que han oído en su casa» (E3). 
lidad, árabe y bereber - viene a solaparse con la oposición entre urbanita y rural. Los rifeños son mirados, en ocasiones — no siempre-, con distancia por los adolescentes árabes y considerados negativamente en razón de un excesivo tradicionalismo que los convierte en maridos indeseables para ellas, porque suscriben un modelo familiar patriarcal donde el papel subordinado de la mujer se lleva a extremos inadmisibles ${ }^{7}$.

De todos modos, insistimos en que generalmente los entrevistados no hacen referencia espontánea a su grupo étnico — identifican «árabe» $\mathrm{y}$ "marroquí»— ni al ajeno, y sólo a mi requerimiento se pronuncian sobre el tema: priman el sentimiento de nacionalidad compartida y la comunidad experiencial como inmigrantes.

5) Españoles: el español deviene «otro» sobre todo por no musulmán (con frecuencia, los discursos recogidos oponen los términos español-árabe o español-musulmán, puesto que se asimila lo español y lo cristiano). Aunque es respetado, el cristianismo no es "la» religión, pero es una de las religiones del Libro y la más próxima al islam, siendo así que comparten profetas y la ética del respeto y la compasión, aunque sobre tal extremo no exista, por lo general, conciencia entre los informantes, que suelen tener una idea confusa del cristianismo. El español, además, es «ateo»: muchos jóvenes refieren con asombro que la mayoría de sus compañeros se declaran "ateos», afirman no creer en nada. Desde los coetáneos, se generaliza a los españoles, y de la ausencia de práctica (ritual) religiosa se infiere ausencia de creencia o de inquietud por lo numinoso.

En segundo lugar, el español deviene "otro" a partir de la vivencia - ocasional pero casi generalizada - de discriminación o rechazo, procedentes casi siempre de desconocidos y personas de más edad: los agravios xenófobos o racistas son más frecuentes ante quienes incorporan (Goffman, 1970) «identificadores externos» (pañuelo, chilaba, fenotipo o acento marroquí). Al referir tales situaciones, los chicos, por lo general, fingen indiferencia pero es evidente que les afecta y que reaccionan, primero con confusión y después generalmente defendiéndose con contundencia ${ }^{8}$. De todos modos, ninguno afirma taxativamente que los españoles sean racistas —unos sí y otros no- y no suelen emitir interpretaciones de dudosa con-

7. «Son un poco raros, la verdad. Son más estrictos y eso... Un rifeño que esté casado es más estricto con su mujer que, vamos, que un árabe que esté casado. Que ellos tienen el islam, pero lo tienen cogido por abajo, porque, vamos, no lo tienen cogido bien» (E11).

"[...] $p a$ mí son iguales [los marroquíes árabes y los rifeños]. Los "marroquíes-marroquíes”, mejor, pero los otros también. Que los otros no les entiendo, no sé... Los rifeños esos suelen tener otros pensamientos» (E8).

8. «No [no se siente diferente], más cuando la gente dice, por ejemplo: "Ay, pobre chica, tan jovencita ahí y no sé qué, con el pañuelo...”, eso me deprime un poco [...]. Me lo pongo porque me gusta y tú no eres nadie porque digas lo que tengo que hacer, lo que yo tengo que hacer. Si a ti no te gusta, bien, pero a mí me gusta. Mira, yo elijo mi cultura, y mi religión me pide que me lo ponga [...] Y que me digan eso, pues no tienen ningún derecho, y eso ofende, es normal» (E10). 
sistencia: saben cómo medir, han aprendido a descodificar conductas y expresiones?.

Finalmente, consideramos adecuado referir las impresiones de nuestros interlocutores sobre España: aunque «España» no son los «españoles», lo predicado del país puede considerarse indicador del grado de vinculación emocional a los españoles y, por ende, de la identidad personal ¿Qué significa España para estos chicos? De nuevo, aquí el «otro» de referencia es la clave: ante Marruecos, España es la segunda patria; ante emigrados a otros países europeos, España es el país de uno. Así suele ser generalmente. Pero a veces — pocas de forma evidenteEspaña sale muy mal parada, porque el grado de descontento vital es enorme: se mezclan diversas razones, casi todas de índole económica ${ }^{10}$ (dificultad de acceso a empleos ajustados a la propia cualificación, debilidad del Estado de bienestar), también la vivencia del rechazo al moro, problemas de acceso a la nacionalidad española, empeoramiento de la situación familiar tras la migración, etc. El referente europeo, idealizado a partir de los relatos de otros parientes emigrados, eleva expectativas y genera frustración, a veces también manifiesta en la añoranza de un Marruecos que cobra tintes idílicos desde el descontento actual, pero al que casi nadie querría ahora volver. Así pues, el descontento personal se traslada a la descalificación de España como país relativamente atrasado en el entorno europeo: es un resentimiento que quiere justificarse desde lo "objetivo", pero que se sustenta menos en vivencias reales de precariedad o marginación que en expectativas frustradas por desmesuradas, en proyecciones de alternativas no realistas e incluso en discursos mediáticos al uso ${ }^{11}$.

9. «Siempre hay alguien que te está dando la vara, siempre. Yo que sé, no sé, porque..., yo qué sé, ven mi nombre o me ven con mi madre [lleva pañuelo], no sé; por cualquier tontería [...]. O sea, a mí unos me llaman, por ejemplo, algunos me llaman Idris y otros me llaman "moro". Como ya están en confianza y son amigos, me llaman "moro"» (E9).

«Si me dicen "mora", "morita", no sé qué, no [no le molesta]. Pero si me dicen "mora de mierda" o lo que sea, pues...» (E6).

«Es normal, en cualquier país hay racismo, hay xenofobia..., o sea, las culturas no se entienden y a lo mejor chocan un poco [...] yo creo que la gente mayor, no es por ofender ni nada, son más..., siguen teniendo esa imagen de que cada uno en su país y que cada uno en su terreno, ¿sabes? [...] Siempre tiene que haber un motivo para descalificar, perjudicar a otros, ¿̇no? No solamente me refiero al islam, también en los latinoamericanos, ya no por concretar en los musulmanes [...] y más adelante, ojalá Dios no quiera, ocurre cualquier tipo de choque entre ellos y este mundo de España, pues pasará algo y hay otro motivo para señalarles con el dedo" (E7).

10. El informe elaborado por el Pew Research Center (2006) a partir de una encuesta a musulmanes mayores de dieciocho años pone de manifiesto que entre los musulmanes que viven en Europa la preocupación económica se antepone claramente a las de índole cultural o religiosa. En España, el 55\% de los encuestados se muestran muy preocupados por el desempleo. Muy preocupados por el declive de la religión, por el extremismo islámico, por la influencia de la cultura pop y por los roles modernos de las mujeres se declaran el $18 \%$, el $22 \%$, el $17 \%$ y el $10 \%$, respectivamente.

11. «Y dicen: "Es que los moros vienen aquí, a por trabajo, y nos quitan, los extranjeros, nos quitan no sé qué...”. Y eso, ¿qué tiene que ver? Gracias a los extranjeros, España..., porque hace diez años o quince años, España era una mierda, y todo, y lo sigue siendo» (E2). 
6) Marroquíes no inmigrantes: son identificados como «ellos», porque, a diferencia de los emigrados, tienen una percepción errónea de las condiciones de vida en España y en Europa en general: «ellos» no saben y «nosotros», los emigrados, «sabemos», sabemos que las cosas no son como parecen y que en España la promoción económica exige trabajar mucho ${ }^{12}$. Nuestros interlocutores son conscientes de que los propios inmigrantes fomentan la confusión entre sus paisanos con la exhibición veraniega de una panoplia de bienes: estos reciben a sus familiares y paisanos tan bien como cabe esperar, dados su carácter hospitalario y la prodigalidad siempre esperada de los veraneantes. Pero esos veraneantes han crecido en España y a veces extrañan los valores y las conductas propios de su país de origen, gratamente con frecuencia y otras veces con sentimiento de distancia.

7) Marroquíes inmigrantes en otros países europeos: son, en ocasiones, familiares también emigrados o simplemente paisanos conocidos durante las estancias veraniegas en Marruecos. La afectividad diferente de uno y otro contacto genera diferentes respuestas: cuando no es familia, el inmigrante en otros países europeos suele ser mal visto por poco marroquí — abandona su lengua de origen-y por su tendencia a la ostentación consumista. Cuando se trata de parientes, esa misma ostentación y el relato de la forma de vida en el país de que se trate tiene efectos muy diferentes: los parientes inmigrados a otros países europeos facilitan información acerca de la situación allí, y ello propicia entre los familiares en España un considerable descontento en relación con su vida aquí. En El Dorado europeo - Francia, Bélgica, Holanda - el Estado apoya más a los jóvenes, es más fácil conseguir trabajo acorde al propio nivel de estudios, no hay tanto racismo ${ }^{13}$, etc. Aunque es sabido que la norma entre los inmigrantes es adornar su situación vital en el país receptor, parece también cierto que entre los inmigrantes también hay clases y que los marroquíes en España se perciben por debajo de los instalados en otros países europeos - aunque se parapeten a veces en el desprecio al parvenu.

8) Otros inmigrantes: los compañeros de clase o vecinos en el barrio de origen latinoamericano constituyen otro referente de importancia entre los

12. «Ellos se creen que $n a$ ' más venir ya lo tienen todo, pero es que hay que trabajar [...] ellos se creen que..., que yo tengo más que ellos por estar viviendo en España. Pero no, en realidad es lo mismo. Y sobre todo la gente que vive en el pueblo, que, no sé, llegas de España y es como si ... [ríe] si hubiera llegado el rey» (E8).

«Ellos ahora cuando ven, por ejemplo, a mi padre con un 4 x 4, un Mercedes, dicen: "Mira ese, no sé qué, buah, yo quiero tener lo mismo". Sí, pero mi padre lleva aquí casi veinticinco años y tú no» (E9).

13. Los resultados del citado informe del Pew Research Center muestran que el 31\% de los musulmanes en España considera que la mayoría de europeos o bastantes son hostiles a los musulmanes y una cuarta parte refiere haber tenido alguna mala experiencia personal en razón de su raza, etnia o religión. No son cifras alentadoras, pero son significativamente mejores que en Gran Bretaña, Francia y Alemania. En el extremo, el 37\% de los musulmanes en Francia refiere malas experiencias y el 51\% de los musulmanes en Gran Bretaña considera que la mayoría o bastantes europeos son hostiles a los musulmanes. 
marroquíes. Los ecuatorianos son el grupo identificado con más nitidez en Madrid, en razón de su mayor presencia relativa y de la rapidez con que se han establecido en barrios donde están asentados los marroquíes, a veces desde hace décadas. Esto ha generado en parte de la población marroquí el mismo sentimiento de desposesión que la española refiere en relación con la extranjera: los nuevos emigrantes se apropian de recursos sociales y están dispuestos a trabajar por menos salario, de modo que arriesgan conquistas laborales que los marroquíes, en tanto población asentada definitivamente, no quieren perder y disminuyen por ello sus posibilidades de encontrar trabajo. Por otra parte, de los latinos en general llama la atención su religiosidad y su trato cortés, aspectos ambos que son considerados positivamente (en contraste, se refiere con extrañeza el carácter poco respetuoso del trato de hijos a padres o a profesores entre los españoles), no así las bandas juveniles, por violentas y porque operan con códigos considerados ilícitos (palizas en grupo, etc.).

Finalizamos este apartado reiterando lo ya dicho: la identidad se construye también sobre la identificación y, en este sentido, el grupo de origen - no hablamos ya de la familia - ayuda al individuo a definirse: el reconocimiento de que es objeto en tanto paisano y correligionario - patente en señas de complicidad, en la simpatía anticipada, la connivencia implícita, los saludos de desconocidos que adivinan el origen común- ofrece al adolescente un «nosotros» que colabora en el proceso de (re)construcción identitaria ${ }^{14}$.

\section{Respuestas identitarias entre los marroquíes}

A partir del análisis de los discursos recogidos, hemos inducido diferentes modalidades identitarias. No se trata de opciones excluyentes, pero ciertamente en cada individuo cobra mayor peso determinado registro. Hemos de advertir, además, que aunque la identidad se construye siempre «frente» a otro, ello no significa generalmente "contra» otro, de modo que la diferencia no resulta, por lo general, incómoda para nuestros entrevistados ${ }^{15}$.

\subsection{Afirmación orgullosa de la identidad marroqui}

La identificación más frecuente y espontánea entre los entrevistados de origen marroquí es precisamente "marroquí», ya se trate de nacidos aquí o en

14. «Pasan, por ejemplo, un grupo de moros, les quieren robar [a unos españoles]. Voy yo, empiezo a hablar con ellos en moro y ya está, y se empiezan a reír conmigo y me abrazan y “qué tal?” y esto. Eso es lo que yo veo normal, que hablas con ellos y es como tu hermano [...] Es como los gitanos, que son como familia, pues nosotros también» (E9).

15. Hay que tener en cuenta que el hecho mismo de la entrevista significa receptividad y apertura al extraño. Los adolescentes que no han accedido a nuestra solicitud pertenecen en ocasiones - a decir de quienes los conocen - a familias más "cerradas», y esa reticencia ha de entenderse igualmente significativa, aunque los motivos concretos no hayan podido rastrearse aquí. 
Marruecos, reagrupados tempranamente o ya casi adolescentes, con o sin nacionalidad española. Dicha afirmación orgullosa se manifiesta explícitamente en la exhibición de rasgos o conocimientos propios de la religión y la cultura de origen, pero no es incompatible con la valoración crítica y la distancia respecto de algunos usos culturales propios del país de origen: los marroquíes de España afirman con frecuencia tener "pensamientos» diferentes a los de Marruecos y también manifiestan escándalo ante conductas observadas en el país de origen durante sus estancias veraniegas (soborno policial, engaños, etc.). Hemos de precisar, además, que el identificador "marroquí» subsume muchas veces la propia condición musulmana: es difícil determinar cuanto pesa la adscripción religiosa en la identificación como «marroquí», porque se entiende que se trata de registros, nacional y religioso, que se superponen.

Sea como fuere, podemos concluir, sin lugar a dudas, que la «identidad étnica fuerte» —en términos de Phinney (1991) — es la pauta más extendida entre los adolescentes de origen marroquí. Una de las principales razones, creemos, radica en que Marruecos está presente en la vida de estos chicos, no solo indirectamente - a través del relato de sus padres y de la televisión marroquí; de hecho, los medios de comunicación sustentan identidad, en positivo los del país de origen y en negativo los del receptor ${ }^{16}$ - , sino anualmente en sus visitas veraniegas. Son visitas añoradas, puesto que la imagen de Marruecos está, por lo general, idealizada, porque es tiempo exento de estudios, de prisas y - para las chicas - del estricto control que sobre compañías y horarios padecen en España. Además, y sobre todo, permiten el trato con el resto de la familia, que arropa y propicia que en España se sienta regusto a soledad. Es sobre todo por la calidez de las relaciones personales y la mayor quietud de la vida cotidiana que muchos proyectan volver a Marruecos cuando termine su vida laboral. Hay discursos - menos- donde se pone de manifiesto una mirada más crítica, que no elude la referencia a aspectos «feos» o mejorables de Marruecos y los marroquíes ni el ejercicio de contraste con España y los españoles. En todo caso, los entrevistados que con mayor arrobo hablan de Marruecos no son necesariamente los que han nacido allí, sino que suelen ser nacidos aquí.

16. "Mi padre vio un documental, un documental en la 2 , y es que era horripilante... Es que digo: “QQué vergüenza: mañana me va a preguntar todo el mundo qué es eso!", porque pusieron Marruecos, pero directamente el lado oscuro [...] se fueron a los sitios malos; por ejemplo, a la gente, pues yo qué sé, hay mucha gente guapa en Marruecos, pero siempre enseñaban a los feos [...] Lo hacen aposta para tener una mala imagen, que tenemos una mala imagen» (E5).

«En primaria, yo me acuerdo que los niños pequeños no le dan tanta importancia al hecho de que seas, de que tus padres sean de fuera, ¿no? [...], no le dan la más mínima importancia, a menos que no salga un tema y la profesora [diga]: "Oye, mira sí, ya que tus padres son..., o tú mismo...” [...] En cambio, en el instituto es un poco más..., opiniones... Yo siempre le echo la culpa a la tele, porque la tele es lo que distorsiona muchísimas cosas de las que están pasando ahora, por ejemplo, de Mahoma y demás» (E7). 
Una segunda razón que consideramos fundamental en la opción identitaria radica en el origen de los padres: uno es marroquí porque sus padres lo son. La herencia cultural es fundamental en la autoidentificación y en la identidad: los propios orígenes son los de los padres y otra identificación es considerada como gesto desleal. Cualquier marroquí que manifieste signos de desapego respecto del propio origen es despreciado ${ }^{17}$.

Por supuesto, hemos de considerar la condición sine qua non de referencia al registro identitario: su significatividad para el interlocutor es este caso el español. "Marroquí» es un registro que reconocemos en virtud de su honda presencia en el imaginario español y que también el resto de los inmigrantes acaba identificando con claridad precisamente a través de nuestra mirada ${ }^{18}$. Podría así considerarse que «son» marroquíes porque los definimos como tales a través de las políticas gubernamentales, la legislación, la discriminación laboral, los insultos en la calle, los discursos mediáticos, etc. ${ }^{19}$. Y, sin embargo, creemos que esta es una visión parcial que niega el papel activo de la minoría: encontramos en los marroquíes una clara voluntad de preservación cultural ${ }^{20}$ - sobre todo religiosa y lingüística: el adoctrinamiento paterno durante la infancia se refuerza en la adolescencia, particularmente en las chicas, con clases periódicas de árabe y de religión o incluso con el ingreso de la prole en centros educativos árabes en lugar de españoles- que no ha de interpretarse, por lo general, como deseo de separación o rechazo del otro, pero sí de mantenimiento de parte de lo propio, porque sustenta la propia identidad o porque, sencillamente, se

17. «Pues yo nací aquí, pero me siento muy marroquí que español. Lo que no voy a ser, toda mi familia marroquí, yo voy a ser español... Yo nací aquí, pero yo soy marroquí, yo hago todo lo del islam» (E4).

«Porque hay muchos aspectos que a mí no me gustan de ellos y dicen: "No, no, si yo he nacido aquí soy española", "pero ¿̇tú eres española?, ¿̇tus padres de donde son?” [...] o sea, una cosa es nacer aquí y otra ser español, o sea, tus padres..., o sea, mis padres, por ejemplo, son árabes, de origen árabe, su abuela lo mismo... Entonces ¿̨de qué van a ser mis hermanas españolas? [ellas nacieron aquí]» (E2).

«A mí, la verdad, no me gusta un marroquí que se haga el español siendo marroquí, no me gusta porque rechaza, es como rechazando su cultura y eso no me gusta para nada» (E5).

18. «Pero a mí me ven como moro, ¿entiendes? [habla de vecinos chinos y negros], aunque sea español, me ven como moro, aunque les diga: "Yo soy español", me dicen: "No, tú eres moro". No se les va de la cabeza» (E9).

19. Tal como afirma Bauman (2003: 86): «Esas diferencias no se derivan de los atributos de la minoría en cuestión, y mucho menos de cualquier estrategia que pueda seguir la conducta de los miembros de la minoría. Las diferencias se derivan del contexto social en el que fueron convertidas en lo que son: de la naturaleza de esa adscripción impuesta que condujo al confinamiento".

20. En apoyo a esta tesis, se ofrecen algunos resultados del informe del Pew Research Center (2006). Encuestadas las poblaciones musulmanas en diversos países europeos, un porcentaje significativo responde que los musulmanes recién llegados a su país quieren en su mayor parte "ser distintos a la sociedad mayoritaria» (frente a la opción "adoptar las costumbres y el modo de vida» del país receptor): 52\% en Alemania, 35\% en Gran Bretaña, 27\% en España y $21 \%$ en Francia (ciertamente, nosotros hablamos de "marroquíes», no de "musulmanes», pero, como se verá, la voluntad de preservación cultural entre los marroquíes es sobre todo voluntad de preservación religiosa). 
considera preferible a lo ajeno. La norma, empero, es que esa voluntad de preservación no se supedita a las exigencias prácticas de la supervivencia y promoción en España ${ }^{21}$, aunque en ocasiones dificulta, por ejemplo, el logro escolar, incluso entre quienes han nacido aquí. Que esta voluntad de preservación cultural se manifiesta sobre todo en exigencias de conformidad cultural en la mujer, nos parece claro. Que esta diferencia en el grado de control del grupo tiene consecuencias identitarias individuales, también: la conciencia étnica de ellas puede ser más intensa.

La afirmación orgullosa de la identidad marroquí se manifiesta en la recuperación como "otro" significativo de los descendientes de marroquíes emigrados a otros países europeos, sobre todo Francia. De modo no generalizado pero sí significativo, los hijos de marroquíes en Francia enfadan por aculturados y prepotentes ${ }^{22}$, siendo así que muchos de nuestros entrevistados se precian de hacer uso en el trato con los marroquíes de Marruecos de ademanes cercanos, de no alardear ante ellos, de comportarse como uno más.

\subsection{Condición musulmana}

Si en la autoidentificación espontánea y explícita el registro casi generalizado es «marroquí», el contenido de los discursos recogidos obliga a considerar su estrecha vinculación a la adscripción religiosa musulmana. Efectivamente, la relevancia del islam en la vida de los adolescentes de origen marroquí se manifiesta de manera inequívoca ${ }^{23}$. El registro «musulmán» como identificador no es el único indicio de esta opción identitaria: el uso relativamente frecuente del término «árabe» y su empleo habitual en relatos sobre el islam permite afirmar que los entrevistados asocian más

21. «Pues estoy [estuvo] en un colegio árabe por nuestro bien, que estudiáramos árabe y no perdiéramos nuestra cultura y todo eso. El [su padre] decidió que fuéramos a un colegio árabe. Pero después del colegio, $p a$ ' cambiarme al instituto, peor todavía [...] si termino en un instituto árabe va a ser muy difícil para ir a la universidad, hay un nivel muy alto y va a ser muy difícil [...] Porque la que va a estudiar soy yo, no él. Pa’ mí es la que va a ser difícil, no para él» (E10).

«Bien, pero con dificultades..., con el idioma y eso... Lo que pasa es que en casa hablamos en árabe y entre mis amigas siempre hablamos en árabe» (E11).

22. «Los franceses eso no lo controlan, ¿entiendes? Encima empiezan a hablar [en francés]: “ipós estás en Marruecos, joer es tu país, habla en árabe!”. O sea, yo voy a Marruecos y hablo en árabe, estoy en España y hablo español..., por respeto a la gente ¿̇entiendes? [...] Mi padre se cabreó, y ¿qué pasa?, gritó alto en marroquí: “Joder!, pero qué pasa aquí, que nadie sabe hablar en marroquí o qué? ¿De qué sangre sois, que no sé cual es vuestra procedencia? ¡Que habréis nacido en Francia, habréis hecho lo que os dé la gana, pero la vuestra es sangre marroquí y tenéis que hablar marroquí aquí ya!"» (E3).

23. Estos hallazgos son también compatibles con los resultados del informe del Pew Research Center: «la religión es central en la identidad de los musulmanes europeos. Con la excepción de Francia, tienden a identificarse a sí mismos en primer lugar como musulmanes antes que como británicos, españoles o alemanes» (2006: 3; la traducción es mía). 
dicho término a la religión [árabes = musulmanes] que a la nacionalidad, y aún menos a la etnia ${ }^{24}$.

Por otra parte, aunque los entrevistados afirman, de modo casi generalizado, cumplimiento de los preceptos islámicos (cuestionable entre los varones, a tenor de las conductas que refieren), no todos señalan la religión con igual contundencia como factor autoidentificativo. Entre las mujeres es más frecuente y es tan significativo esto como su empeño en dar a entender que se trata de una libre elección, interpretable como una reacción al discurso victimista sobre la mujer musulmana que ofrece Occidente. Es significativo también que la referencia al islam entre ellas se vincule inmediatamente y motu proprio al uso del pañuelo, que se entiende indicador de religiosidad —en algunos casos, sin embargo, se niega su relación con el islam, se dice que es solo una "costumbre»- y sobre todo señal de completa respetabilidad en la mujer, aunque en ocasiones se racionalice afirmando que el gesto externo no garantiza la virtud. En todo caso, acarrean cierta culpabilidad por no llevarlo y se justifican en el carácter irrevocable de la decisión, que exige completo convencimiento (todas las entrevistadas afirman que más adelante lo llevarán, aunque algunas pertenezcan a familias donde ninguna hermana mayor lo lleve). Con la decisión culminará el compromiso religioso.

La referencia al islam implica también la referencia a ciertas conductas no permitidas que tienen repercusión directa en las formas de ocio y en redes de relaciones de los adolescentes. Entre lo prohibido figuran el tabaco, las drogas, las discotecas, las relaciones sexuales prematrimoniales, etc. El «buen musulmán» es quien respeta tales prescripciones, y con mucha menos frecuencia se ofrece una descripción más ortodoxa — los cinco pilares - o menos ritualista — dimensión ética- del islam ${ }^{25}$. A este respecto, es significativa la disocia-

24. «Marruecos estoy orgullosa de ella, estoy orgullosa, o sea, de serlo y de ser musulmana; en general, estoy muy orgullosa» (E2).

"Aunque haya nacido aquí, pero yo soy marroquí porque sí, porque mis padres son marroquíes y yo soy marroquí. Yo practico la religión islámica, no la católica, entonces pues yo me siento marroquí» (E8).

«Antes..., antes musulmana. Claro, porque es mi religión. Y española. Pues española porque he nacido aquí y me he criado aquí y siempre seré española, pero musulmana primero» (E10).

25. «Hay muchos niños y niñas, marroquíes y eso, no sé si les da vergüenza o algo, no sé, pero siempre dicen lo mismo: que es que hay una parte [del cerdo] que no hay que comerla, eso siempre te lo dicen... Entonces, como no saben qué parte es, pues no comemos... Eso es mentira... Igual que lo del Ramadán... Pues, ¿̇de qué se trata?, pues porque Dios, porque nuestro Dios, Dios nos lo ha dicho; todo lo que nos diga Dios lo hacemos, sin explicaciones, ¿entiendes? Si Dios nos dice una cosa, hay que hacerla sin..., pero si es que me ha creado, pues es que yo hago todo lo que me diga él, es que no me hace nada que me perjudique, la verdad» (E5).

«Tú empiezas a ser un hombre, pues ahí ya tienes que empezar a rezar obligatoriamente, ahí hasta que te mueras. Y ahí ya tienes que saber, tienes que aprender, no tienes que mentir, no tienes que..., yo qué sé, irte con chicas, o sea, acostarte con ellas [...] no tienes que ir a las discotecas... Bueno, discotecas sí, pero es que a las discotecas se va a ligar y eso de ligar ahí no se puede; no tienes que comer cerdo, tienes que rezar obligatoriamente las cinco veces del día..., o sea, muchas cosas» (E9). 
ción relativamente habitual en los varones entre su conducta y lo que consideran adecuado, disociación mucho menos frecuente entre ellas. Esto responde a la existencia de diferentes patrones de permisividad social. Es decir, no existe relación necesaria entre aceptación acrítica del islam y cumplimiento rígido de sus preceptos. De hecho, se observa una religiosidad — también en su dimensión ritualista - de mayor profundidad en quienes refieren crisis de fe, cuestionan ciertos aspectos de la ortodoxia o la interpretan de modo más «personal» 26 .

En tercer lugar, la afirmación orgullosa de la adscripción musulmana parece resultar, de modo más evidente que cuando hablamos de identidad marroquí, de una suerte de "carrera moral» (Goffman, 1970) que se inicia en la infancia. Una carrera que en sus inicios vendría marcada por el dilema, la duda, el desgarro asociado a la aceptación de un marcador que distingue y la renuncia a la asimilación y terminaría generalmente en la asunción de la propia diferencia, muchas veces sublimada, y en la demanda de respeto y defensa contundente frente a toda ofensa en este sentido (no se refieren problemas en el ámbito escolar). En todo caso, hay que destacar que los entrevistados no perciben el islam como un obstáculo para vivir en España y que no reclaman trato diferencial en virtud de su condición musulmana.

Así pues, la afirmación orgullosa de la condición marroquí es la norma entre los entrevistados, de modo que siempre se antepone al registro «musulmán» como identificador, aunque sean frecuentes los prolijos discursos acerca de las bondades del islam y de su importancia vital. Si tomamos como referencia la población musulmana en contextos migratorios más antiguos como Reino Unido, se constata que el registro identificatorio nacional era el más frecuente entre los inmigrantes de primera generación y que la identificación musulmana se percibe sobre todo en la tercera, fenómeno que se entiende ligado a la frustración asociada a los valores occidentales y a las políticas multiculturalistas británicas, que, paradójicamente, han reforzado la diferencia: «Older migrants are much more likely to identify with their ethnic or nacional identity, whilst identification with Islam is much more prevalent amongst

26. «La religión, la tengo muy presente [...] Siempre que hago alguna acción o cualquier cosa, está ahí presente, porque desde muy pequeña [...] siempre ha estado inculcado, muy inculcado, y, quieras que no, siempre me he planteado muchas veces: "pero, ¿soy musulmana porque quiero o porque así han sido las circunstancias de la vida y mis padres me lo han puesto de esta manera?" [...] yo cuando, es una forma de expresión típica, cuando hablo con Dios: "Dios mío, perdóname porque yo no tengo la culpa de haber nacido en un país como este y el tener tan cerca y tan presente costumbres y cosas que tenga que ver el día a día y que alguna vez que otra he tenido que resbalar en ellas, he resbalado y yo he querido resbalarme, pero si he cometido una tentación y tal, lo único que te digo es que me perdones, rectificar y seguir adelante", pero no un remordimiento de decir...: "Me arrepiento, es que jamás lo vuelvo a hacer", y sabes que podrías volver a hacerlo" (E7).

«Es que hay muchos tipos de musulmán. Yo ahora mismo soy musulmán, pero he convivio, pues, no sé, con otras religiones, con otras culturas, con gente que ni cree en Dios [...] Yo creo en Dios, pero no Dios te tiene que decir lo que hacer. Pá mí Dios nos ha dejao en la tierra, o sea, nos ha dao vida y ha dicho: "Haz lo que hagas, el último día hablaremos"» (E3). 
the younger generation. Arguably, the strong identification with the transnational ummah is relatively new» (Azira et al., 2007: 21) ${ }^{27}$.

\subsection{Rifeño}

La afirmación de la condición «rifeña» se compatibiliza con otras, claramente también con la condición marroquí, pero no aparece como registro de autopresentación en primera instancia. Solo entre marroquíes lo rifeño tiene significado; cuando se habla ante un español, de España y/o de la propia vivencia aquí, no se es rifeño, sino marroquí. El «otro» en este caso es el también marroquí pero árabe, citadino, que es contemplado como menos de fiar que el rifeño (persona recta, honrada, de una sola palabra).

\subsection{Identidad territorial o vecinal}

La cotidianidad de la vida en el barrio, la posibilidad de conocer y ser conocido, catalizan el desarrollo de cierta identidad territorial que se superpone a otros identificadores y presenta, a diferencia de algunos de ellos, una dimensión integradora de las diferencias culturales. Tener antigüedad en el barrio y en el instituto permite apropiarse del espacio, genera sensación de seguridad y posibilita reconocerse a través del (re)conocimiento ajeno ${ }^{28}$. Esta identidad no se desarrolla, empero, en todo caso, solo cuando el entorno es amable y su identificación no denigra al entrevistado.

Sobre este punto, nos parece clara la necesidad de hacer un estudio más profundo, aunque ya en el nuestro se corroboran algunas apreciaciones derivadas de los estudios de la Escuela de Chicago, particularmente los análisis de Park, y también los trabajos de Bourdieu, donde nunca se ha desatendido la importancia del entorno físico - que es también moral, como refiere Park- en la comprensión de la conducta humana ${ }^{29}$. En nuestro caso, los entrevistados han sido seleccionados en dos barrios madrileños de características muy diferentes ${ }^{30}$. Por una

27. Husband, precisamente, refiere cómo entre las generaciones más jóvenes de pakistaníes en Gran Bretaña el identificativo «musulmán» es más frecuente que "pakistaní». Mientras entre los progenitores se mantienen fuertes lealtades clánicas y tribales reforzadas por los usos lingüísticos, entre los jóvenes tales lealtades se debilitan y perciben que tiene más significado social la identidad religiosa que la identidad nacional-étnica: «ven el término "musulmán” como algo que tiene credibilidad política y social» (2001: 104).

28. "Antes eso era como una ciudad, ¿entiendes?. Uno era de Barajas, pues eres de Barajas y ya está. O sea, no tienes ni país ni nada» (E3).

29. En La miseria del mundo (Bourdieu 1999), el oficio de sociólogo se exhibe en toda su complejidad y con virtuosismo. Varias entrevistas se refieren directa o indirectamente al fenómeno migratorio en sus múltiples implicaciones, también en relación con los procesos identitarios de los protagonistas.

30. Hemos de tener en cuenta que estos jóvenes, sobre todo las chicas y los residentes en el barrio más depauperado, apenas salen de él en su tiempo libre, de ahí que ello cobre más importancia relativa en la construcción de su identidad. De este modo, el efecto «oxigenante» del contacto con lo diverso que posibilita la ciudad no se verifica en estos grupos cerrados. 
parte, el barrio de Lavapiés, que responde perfectamente al modelo trazado por Park en su descripción del proceso y las consecuencias del crecimiento acelerado del centro urbano: retención especulativa de los inmuebles, lo cual incrementa su deterioro, y conversión del barrio en zona de tránsito poblacional para juventud inestable, gente de vida bohemia, inmigrantes con pocos recursos (con frecuencia, familias desestructuradas y también menores no acompañados) y en régimen casi generalizado de alquiler, que vienen a sumarse a los antiguos vecinos que no pudieron escapar de un entorno que, además, presenta un significativo nivel de delincuencia. Se produce entonces un proceso de segregación de población, también en el seno de los propios grupos de inmigrantes, de manera que «la fracción más dinámica, enérgica y ambiciosa de la población de esos guetos y de esas colonias de inmigrantes los abandona rápidamente para instalarse en otras áreas de inmigrantes de segundo asentamiento, o quizá se instale en un sector cosmopolita donde inmigrantes y grupos étnicos diversos cohabitan» (Park, en Martínez, 1999: 93). El segundo barrio, Valdebernado, es periférico, resultado de la anexión y la ampliación planificada de un pueblo de la corona metropolitana, con infraestructuras nuevas, amplias vías, espacios de recreo y culturales; migración familiar y ocupación en régimen de propiedad.

La diferencia en el discurso entre uno y otro grupo de residentes es clara, siendo así que la referencia al barrio es más frecuente entre los ubicados en el periférico, que muestran una relación amistosa con el entorno (aunque determinados bloques — «parcelas»— donde reside también población gitana son señalados como conflictivos) y un uso normalizado de los recursos disponibles (biblioteca, centro cultural, etc.). No puede hablarse aquí de «colonia racial» (ibídem: 56), porque no hay apropiación segregada del espacio y se trata de un barrio con considerable proporción de población inmigrante pero no mayoritaria. Por su parte, los entrevistados refieren el barrio degradado como entorno hostil, estigmatizado y estigmatizador. Se verifica aquí una apropiación espacial segregada, de modo que ciertas zonas son evitadas por tratarse de un lugar de deambulación de pandillas de chicos dedicados al trapicheo y al consumo de hachís. No existe propiamente vecindario: el control social solo funciona para proteger al etnogrupo de sí mismo - los entrevistados se jactan de su inmunidad frente a delincuentes compatriotas y correligionarios-, pero no a los demás grupos. El trasunto moral del espacio se manifiesta, entre los entrevistados de Lavapiés, en desapego respecto al barrio y en un menor nivel de ambición personal, de expectativas de futuro.

\subsection{Marroqui-español o hispanomarroqui}

Esta opción se concreta en una clara bilateralidad de referencias: uno se siente de las dos partes pero de ninguna por completo, porque en Marruecos es

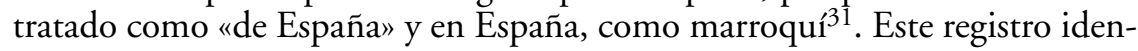

31. «Ahora yo soy español, ¿no?, que $p a$ ' ellos [los marroquíes en Marruecos] yo soy español. Yo también... O sea, he nacido en España. Yo sé que soy español, pero muchas veces se lo 
titario se da entre adolescentes nacidos en España, y no implica necesariamente monoparentalidad o progenitores de origen mixto. Este delicado equilibrio no es fácil de encontrar, porque las competencias personales precisas para el manejo de esta situación fronteriza implican capacidad de observación y de reflexión, de valoración crítica, de resistencia a la desaprobación ocasional del grupo, etc. Se precisa, además - y este rasgo es requisito pero también consecuencia-, un sentido fuerte del yo, autopercepción como sujeto activo, actor de su adaptación, y también un contexto familiar propicio: progenitores conscientes de las exigencias diversas que afrontan sus hijos. Se trata de discursos elaborados, no improvisados y que, en ocasiones, traslucen cierto orgullo asociado a la capacidad de descodificar registros culturales diferentes ${ }^{32}$.

\subsection{Extranjero}

Este identificativo traduce el sentimiento de comunidad con quienes comparten la condición de inmigrantes, procedan de donde procedan. Como el anterior, este registro es minoritario entre nuestros entrevistados pero es comprensible dada su experiencia vital: ellos y/o sus padres carecen de la nacionalidad española y, por ello, de acceso a ciertos derechos; en el colegio se ven

he dicho a él: "Yo soy español, pero de religión musulmana" [...]. No me tratan como marroquí y en España tampoco me tratan como español [...] en Marruecos me siento español y en España me siento marroquí» (E3).

«Me siento ni muy de aquí ni muy de allí. Me siento..., ¿cómo se diría?, de las dos partes. Cuando viajo ahí, me siento de ahí, es decir, las costumbres, la religión, etc., pues todo esto te llega porque te lo han enseñado tus padres y demás; pero a la misma vez estás aquí y también te sientes un poquito de aquí. Por ejemplo, cuando estás con el público, ¿no?, en el instituto, en la calle..., también el habla, las costumbres, las entiendes pero no las haces, pero te sientes bien [...] Española yo, como digo yo, "hispano-marroquí". Me siento, así, española, pues en el sentido de haber nacido aquí, haber crecido, arraigarme más a la gente, su forma de mirar las cosas, su estilo, ¿sabes? de la vestimenta, por ejemplo, y todo eso... Y de musulmán, pues como lo aprendí desde muy pequeña, que eso crece en ti y lo llevas ahí» (E7).

32. «Ahora, joder, pues hay libertad de opción [...] joder, que ya somos personas, ¿̨no?, que ya, que ya utilizamos la mente, que no era como antes que no podías utilizar tú la mente, que la Iglesia o el..., o sea, la mezquita tenía que pensar por ti...” (E3).

«Yo nunca me he sentido observada por el hecho de decir: "Oye, pues sí, soy de origen marroquí", ni orgullosa ni nada; nunca el centro de atención ni rechazada por ningún tipo de grupo social, gracias a Dios, no. Eso se trata de que tú también te incorpores, te incorpores en sentido de que seas una persona que te guste conversar, escuchar, etc., no el hecho de decir: "Como ellos son diferentes, me aparto y que ellos me vengan a buscar [...] Mi padre es un poco, como le llamo yo, es un poco, el "padre raro de los padres marroquíes"; es esa excepción de padre que nunca nos ha gritado ni nos ha dicho, por ejemplo, el tema del pañuelo [...] nos ha explicado la religión de una manera tan abierta, tan pacífica, tan tolerable, nos gusta tanto, que aunque tengamos que ver todos los días otra costumbre o cultura, nos gusta tanto la nuestra por el hecho de cómo nuestro padre nos la ha hecho ver... Yo esto se lo cuento a un marroquí y no se lo cree, incluso a un español, por cómo está visto - lo que te decía antes - el mundo del islam y demás; no se lo creen. Pero gracias a Dios somos así y eso es lo que hace vivir aquí tan bien acomodados» (E7). 
agrupados en aulas específicas con otros no españoles, etc. Curiosamente, no se trata de un registro más presente entre los recién llegados: estos se identifican como marroquíes, no como extranjeros —el registro cobra así tintes de desarraigo. Por otra parte, en las edades más tempranas, el identificativo suele ser menos frecuente: «extranjero" es un registro elaborado, solo significativo desde la experiencia y la conciencia de desposesión relativa, y se asocia también al convencimiento - lento pero definitivo- de que nada le devolverá a uno definitivamente al país de origen ni le ligará con fuerza al receptor. También se asocia, por supuesto, al constante recordatorio que impone el español ${ }^{33}$.

Para terminar, no hemos encontrado, entre nuestros entrevistados, tampoco entre los nacidos aquí, ninguno que se identifique como «español», lo que seguramente se explica en razón del carácter relativamente reciente de la inmigración marroquí en España, la proximidad de Marruecos, el peso de la familia y del islam, así como el efecto distanciador del español y la política gubernamental frente a los ciudadanos de origen marroquí. Por otra parte, hemos de precisar que cada uno de los vectores implicados en la configuración de las opciones identitarias tiene su propia dinámica y ni siquiera en sí mismo permite realizar una interpretación unívoca: no hay un único islam ni un modelo único de familia marroquí, ni siquiera un discurso mediático único sobre la inmigración, sobre lo moro o lo árabe. Así, su influencia en la configuración de las opciones identitarias no es unívoca y, por otra parte, sus efectos se solapan entre sí (y con los de otras variables como clase social, etnia, antigüedad migratoria, etc.). Cada individuo podría entenderse $-y$ la inteligencia sociológica es solo inteligencia parcial: el «yo» no son (solo) las circunstancias- como manifestación de una configuración específica de efectos cruzados de diversas variables ${ }^{34}$.

33. «Es que, no sé, no me siento tampoco extranjera, porque llevo mucho tiempo aquí, no sé. Pero cuando te dice ahí "vete a tu país", yo qué sé...." (E6).

34. Por eso nos parece arriesgado asumir que la comunidad de intereses genera identidad compartida. Esa parece ser la tesis de Solé y Parella: «Una vez ciudadanos, autóctonos e inmigrantes compartirán las mismas condiciones, bajo los mismos hechos y circunstancias, para alcanzar objetivos comunes. La solidaridad de grupo unirá, a su vez, los esfuerzos de autóctonos e inmigrantes en la consecución de intereses comunes, acción que derivará en un proyecto común de construcción de la identidad como grupo, identidad colectiva» (2005: 19). Ciertamente, tal comunidad de intereses es condición necesaria, pero no es suficiente; tal vez por eso las autoras añaden: «Es, precisamente, a partir de su integración en la estructura ocupacional [...] y social (aceptación de las instituciones sociales y políticas, adopción de las normas, costumbres, valores, lengua, etc. de la sociedad receptora, para la segunda generación), que los inmigrantes obtendrán el reconocimiento como miembros del grupo. A partir de ese reconocimiento, desarrollarán estrategias racionales para actuar en la consecución de nuevos intereses propios (representación política como grupo étnico, por ejemplo), y a la vez comunes y compartidos con los autóctonos» (ibídem: 20). No nos parece claro que la ciudadanía común genere unidad de intereses e identidad compartida (pensemos en los autores del atentado de Londres). Pero, además, se postulan la comunión de intereses y la desaparición del exogrupo como tal —asimilación cultural— como condición de reconocimiento por parte de la población autóctona. Es difícil imaginar cuales podrían ser entonces los «intereses propios» del extinto grupo. 


\section{4. ¿Identificaciones diferentes según género?}

El análisis de nuestras entrevistas pronto reveló que los adolescentes de origen marroquí destacan entre otros también de origen extranjero en razón de su autoidentificación explícita y orgullosa como marroquíes; su voluntad clara de darse a conocer, de explicar, a veces de convencer; así como cierto relativo mayor nivel de reflexión acerca de su relación con el grupo mayoritario. Se trata seguramente del grupo con presencia más definida en el imaginario colectivo español, lo que no puede dejar de tener consecuencias en su autopercepción y su identidad. Consecuencias negociadas por cada individuo según una serie de variables que no actúan de modo unívoco y se manifiestan en identificaciones simultáneas y también alternantes. Pero es claro el predominio de una fuerte identidad étnica.

Una de las hipótesis derivada de nuestra indagación fue la posibilidad de localizar identificaciones diferenciales entre adolescentes en función del sexo, y ello en base a un factor que nos pareció decisivo: el diferente carácter de las redes de relaciones entre varones y mujeres. Brevemente, las redes de relaciones femeninas tienen un carácter más cerrado, progresivamente más replegado sobre familia y paisanos; ellos, sin embargo, se insertan en el seno de redes mixtas que proporcionan modelos valorativos y conductuales diferentes. Si el proceso de construcción de identidad es de carácter relacional, el hecho que referimos habría de tener consecuencias en los procesos de identificación analizados.

\subsection{Repliegue sobre el propio grupo: el carácter voraz de la institución familiar}

Uno de los aspectos con mayor potencial explicativo de la situación vital de las adolescentes es el carácter voraz —en términos de Coser (1978)— de la familia marroquí. Efectivamente, aunque la modernidad se asocia a la disminución de la intensidad con que el individuo se vincula a las instituciones, las denominadas "voraces», «en contradicción con las tendencias dominantes, demandan la adhesión absoluta de sus miembros y pretenden abarcar toda su personalidad dentro de su círculo [...] sus demandas respecto de la persona son omnívoras» (1978: 14). El mayor control ejercido sobre las féminas tiene también que ver con el islam, que refuerza el patriarcalismo. Ramírez (1998) afirma la dificultad de establecer claramente los vínculos entre el modelo patriarcal mediterráneo y el islam, dada la ambigüedad con que el Corán se manifiesta sobre la relación entre hombres y mujeres, pero es evidente que ambos se superponen de hecho en sus efectos, que convergen en la demanda de lealtad absoluta de la mujer a la familia y en las limitaciones a los vínculos que puedan amenazarla.

Así, las entrevistadas refieren en su infancia redes de pares mixtas o incluso españolas. Durante la adolescencia el grupo de referencia, sin embargo, se va nutriendo - fuera del instituto- cada vez más en exclusiva de congéneres adolescentes de su mismo origen, por marroquíes, pero sobre todo por corre- 
ligionarias. Ellas no pueden acceder a las prácticas de ocio usuales entre las españolas porque arriesgan el cumplimiento de los preceptos del islam exponiéndose a la "tentación» (alcohol, relaciones sexuales prematrimoniales, etc.), de modo que el ocio transcurre en el espacio del hogar o es tiempo de compras con parientes o compatriotas, no con españolas, aunque estas siguen siendo amigas en el instituto. Aunque no siempre es así —hay chicas marroquíes que tienen incluso novio español ${ }^{35}$ - , por lo general ellas afirman no pensar en novios (menos aún no marroquíes) hasta que les llegue la edad de casamiento, ni aceptar relaciones prematrimoniales, ni trato de excesiva cercanía con chicos, que en ocasiones entienden como "rebajarse ${ }^{36}$. En las relaciones con los chicos, ellas refieren mayor respeto por parte de los marroquíes, pero les resulta gratificante el trato con los españoles, seguramente porque con ellos existe posibilidad de relación meramente amistosa, no solo porque no puede ser de otro modo, sino posiblemente también porque los españoles, a diferencia de los marroquíes, sí contemplan la amistad — sin más — entre hombres y mujeres.

Por lo general, las entrevistadas justifican sus preferencias amistosas y de pareja — ambas marroquíes-, así como sus opciones de ocio en su libre albedrío, pero son evidentes el condicionamiento cultural y el control paterno ${ }^{37}$. Ciertamente, aquí se ejemplifica el imperativo de hacer de la necesidad virtud, pero resulta significativa la reiteración en la explicación del trato preferente con las paisanas: se comprenden mejor entre sí, dicen ellas (también ellos, pero en menor medida). Esto es lo que, según Bauman, significa «comunidad»: «un entendimiento compartido de tipo "natural" y "tácito"» (2003: 5). Y se comprende mejor, hay que subrayarlo, sobre todo por correligionarias, no tanto en razón del origen nacional compartido ${ }^{38}$.

35. "Aunque sea feo, le dicen que sí pa’ fardear con las amigas. Dicen: "Mira, mi novio es español, no sé qué"» (E9).

36. "No hay que abusar tanto de la confianza. Te ríes conmigo, hablas conmigo, bien, pero nada de "bonita", así nada [...] las manitas, así, así, así, nada" (E10).

37. "Porque es que yo tengo jaqueca y... [risas] y odio. No me gusta nada el "pum, pum, pum" y eso. Es que, mira, no me gusta el bacalao, no me gusta el reggaeton, no me gusta nada [...] es como lo del cerdo, la discoteca, pues tampoco me llama. Es que hay más sitios para divertirse, no sé por qué tanta tontería irme a una discoteca. Es lo último que haría, la verdad» (E5).

«Es que mi madre me dice que mejor me vaya con marroquíes, porque las españolas son más..., y eso, pero yo qué sé. Dice que si es buena y no fuma y eso, "vete con ella"» (E6).

"A mí me miran, por ejemplo, las chicas de..., pues eso, las marroquíes, cuando estoy con un grupo de amigos - por lo que te decía, que me acerco más a los chicos, me gusta más relacionarme con ellos, hablar y tal—, pues me miran de alguna manera..., no mala ni nada, sino que, “jolín, es que esa es tan diferente a nosotras en ese sentido...”. Porque las marroquíes, en general, chicas con chicas y chicos con chicos [...] porque mi padre y mi madre son de mentalidad abierta. Pues eso es lo que te hace pensar de manera más liberal, ¿no?» (E7).

38. «Como somos musulmanas, las mujeres marroquíes, pues, yo qué sé, nos comprendemos más [...] porque a una española le dices eso de no sé qué, no salir de juerga, no sé cuantos, por la religión, pues, yo qué sé, hay algunas que te dicen: “¿Y eso?, ¿¿cómo?, ¿de qué viene y a...?", y más si son ateas» (E11). 
Evidentemente, la identidad de la adolescente está estrechamente ligada al modelo de mujer que le es transmitido. A este respecto, no cabe generalizar: hay hijas que crecen en el seno de familias que mantienen una visión patrimonialista de la prole que las vincula sobre todo a ellas - y su dedicación al estudio se resiente grandemente por ello- y otras cuyos progenitores mantienen elevadas expectativas acerca del logro educativo de sus hijas. El primer modelo va acompañado de presiones al matrimonio temprano y en ocasiones concertado, pero no ha de identificarse con un mayor grado de religiosidad y, de hecho, es criticado en el seno del endogrupo por adolescentes que otorgan al islam un papel rector en su vida (aquí pesan otras variables, como el nivel de estudios de los padres, el origen rural o urbano, etc.). En cuanto al segundo modelo, los padres muestran disposición a posponer el proyecto matrimonial de su hija a la finalización de la inversión educativa, para la que la cobertura paterna se ofrece sine die. Las cesiones paternas, de todos modos, no invalidan la mayor: la familia ejerce siempre más control sobre sus hijas que sobre sus hijos y ni la creciente incorporación de la mujer marroquí al mercado de trabajo ni sus logros educativos significan que su deber primero para con la familia se atenúe. La condición de ser social de la mujer sigue pasando por el matrimonio y la maternidad y el islam mantiene su papel regulador de la sexualidad. En definitiva, el peso de la familia como vector ordenador de la vida de la mujer permanece. La paradoja se revela entonces: es precisamente este mayor control familiar sobre las chicas el principal condicionante de su mayor logro educativo ${ }^{39}$, pero al tiempo con ello abre la puerta a otras relaciones, aspiraciones y posiblemente al cambio cultural en el endogrupo. Es decir, a través de su logro escolar, las hijas ofrecen a sus padres una nueva representación del mundo exterior, menos amenazante, ya no espacio de traición cultural (Hassini, 1997: 186).

Entre las adolescentes entrevistadas, se deja ver el peso de la condición de esposa y madre en sus anticipaciones del futuro, pero casi todas ellas afirman con rotundidad la prioridad de los estudios, aunque ello implique la demora del matrimonio (una «demora» que sigue muy lejos de la media de edad de acceso al matrimonio entre las españolas: se habla de no casarse hasta con 23, 25..., a lo sumo 27 años). Asoma con claridad también la proyección laboral —a la que atribuyen un potencial emancipador que psicológicamente parece compensarles la previsible duplicación de su jornada laboral ${ }^{40}$ —, pero no siempre

39. Tal como afirma Hassini (1997: 5) : «L'éducation familiale et domestique des filles des parents maghrébins anticipe la conformité aux regles scolaires [...] Les filles sauraient ainsi tirer profit d'une éducation normative, ayant acquis la conscience de la nécessité de règles du jeu, d'une discipline, d'efforts et de travail, pour obtenir la participation à la société [...] aux garçons l'excès de liberté dont ils bénéficient ne facilite pas leur aceptacion des contraintes scolaires et nuit à leur bonne scolarité».

40. «Si quiere trabajar [su futura esposa], que trabaje, pero luego tiene que hacer las tareas de la casa. Yo no he dicho que trabaje, yo he dicho que se quede en casa. Le voy a decir: "Mira, tú estás aquí por..., o sea, tú limpias y todo, yo voy, tú estás sentada ná más y yo voy y traigo el dinero a casa, tú solo limpias y cocinas, me dejas la comida encima de la mesa, lo 
profesional: aunque la ambición (alentada por las madres sobre todo, pero no exclusivamente ${ }^{41}$ ) y el logro escolar de las chicas es mayor que en sus hermanos, a veces se es reticente a considerar el paso por la universidad porque se trata de un coste de rendimiento incierto y que obliga a aplazar el proyecto familiar propio - reticencia que, por otra parte, guarda relación con la estimación de las propias posibilidades de logro educativo-

\subsection{Adolescentes de origen marroqui y anomia}

La realidad del adolescente varón es otra, porque los modelos musulmán y patriarcal lo tratan de otro modo: la permisividad social en relación con la conducta del chico es mucho mayor. A ellos se les permiten comportamientos que en sus hermanas serían duramente juzgados - no es tan grave que no obedezcan, que no saquen adelante sus estudios, que tengan amistades de todo origen y prácticas de ocio no recomendables, que tengan novias (normalmente no marroquíes, que son tratadas con el respeto debido a las correligionarias) - y las consecuencias de esta mayor permisividad se atribuyen generalmente - y lo hacen sus propias hermanas - a lo que se considera la rebeldía innata de los varones: se naturaliza lo que es cultural ${ }^{42}$. Otras veces, se cuestiona $^{43}$ o se declara abiertamente el carácter injusto de ese trato diferencial y se reclaman «límites para todos» (E11).

Sin embargo, los discursos recogidos no dan a entender que los varones de origen marroquí disfruten de esta mayor autonomía. De hecho, casi siempre la

único que quiero". Pero si ella quiere trabajar y no encuentro nada de eso hecho, ¿jpa’ qué sirve? Yo estoy tó el día currando, la traigo 3.000 euros encima a casa y tú quieres trabajar: " $i p a$ ' qué?, ¿qué más quieres?” (E9).

41. «Mi madre me lo dice también. Me dice: “Tú elige una profesión que quieras, sólo estudia, estudia, no pienses en casarte ni nada de eso. Que mi madre se casó joven. Yo si me caso, pues, a los 23, 22, por ahí, 25 [...] Hacer algo en la vida, el día de mañana ser algo, no quedarme en casa atendiendo a mis hijos o tó el día pariendo, no [...] Uno tiene que elegir la profesión que quiera él: "tú me has educao [habla al padre], tú has hecho que estudie, vale, yo he estudiado, me has educado, pero el trabajo lo voy a elegir yo. Quiero una profesión que me guste, que voy a trabajar en ella y todo eso" (E10).

"Que a la hora de las notas ya los dos [padre y madre] se vuelven igual. Mi madre, vamos, está loca por los estudios. Y mi padre igual. Es su sueño [...] Que no me dejan ni trabajar, porque me dicen: "Si trabajas, pues ya empiezas a coger dinero, no sé qué del dinero, y vas a abandonar los estudios” [...] Quieren que seamos algo mejor que ellos» (E11).

42. «Sí, más obedientes, porque las chicas marroquíes, por ejemplo, tenemos un carácter entre todas, y eso, que somos muy positivas, todo decimos "sí" a nuestras madres. Los chicos marroquíes un poquito más rebeldes [...] Sí, yo conozco chicos [marroquíes] que van [a las discotecas] y eso, ellos son más rebeldes, son más juerguistas y eso..., como antes te he dicho. No es que tengamos disti..., distinción entre nosotros, o como se diga [...] Siempre cuida la chica [si la madre se pone enferma], pero yo creo porque la madre se cree que tiene más responsabilidad y eso, porque el chico es más tonto» (E5).

43. «Es que una cosa que en teoría no..., no entiendo, nunca he entendido y creo que, Dios me perdone, nunca entenderé: por qué la mujer tiene menos fuerza, menos poder que el hombre en el islam, ¿no? Es una cosa tan compleja que la misma mujer dentro del islam, creyéndolo, ¿eh?, no sabe por qué, pero lo respeta» (E7). 
falta de control paterno aumenta su sentimiento de pérdida y la sospecha de no preocupar a los progenitores. La necesidad de límites de todo niño cobra mayor relieve cuando afronta una situación donde los referentes morales que encara en virtud de su condición de hijo de extranjeros son en ocasiones contradictorios: el chico sabe que no debe fumar, consumir drogas, beber o ir a discotecas, pero lo hace; no debe tener relaciones sexuales prematrimoniales, pero las practica; sabe que hay malas compañías, pero no las elude... Así, por falta de límites o por imposición inadecuada — autoritaria y/o basada solo en el castigo físico-, las situaciones de anomia son más frecuentes entre los varones que entre las chicas y las sufren hasta el punto de que resulta evidente, en lo que dicen y cómo lo dicen, que aman más a quien más autoridad tiene sobre ellos, sea esta figura el padre, la madre o incluso la abuela que permanece en Marruecos, un profesor o educador, etc. ${ }^{44}$. El desquiciamiento les hace sufrir - aunque no sepan expresarlo verbalmente, lo hacen con gestos de despotismo y rebeldía-, seguramente más que a sus hermanas el control excesivo y la falta de elecciones vitales.

Estos chicos dan por sentado que en el futuro formarán una familia y, con frecuencia - no siempre-, que sus empleos serán manuales o poco cualificados. Tienen claro que quieren dinero y suelen estar informados del salario asociado a distintas opciones laborales, pero se les hace muy costoso obtener alguna credencial educativa — generalmente, optan por algún ciclo formativo o módulo de garantía social-, porque sus rutinas de estudio no suelen ser adecuadas, los cursos se aprueban con lentitud y se acumula hartazgo en el sistema educativo. Se quiere dinero, sí, pero los caminos estructuralmente dispuestos se anticipan demasiado áridos.

El control social se debilita con el cambio migratorio - los padres están con frecuencia menos presentes de lo que debieran, las familias se han nuclearizado o monoparentalizado y ya no viven en vecindarios donde son conocidas - y la pauta de relativa permisividad social de que siempre ha disfrutado el varón marroquí se revela aquí, en un contexto social distinto, perniciosa y puede significar una grave falta de referentes morales. Uno de los indicadores más evidentes de esta situación es la presencia relativamente superior entre los varones de lo que hemos dado en llamar "ostentación consumista» (Veredas, 1999) como forma de salvaguardar la autoestima. La fascinación por la ropa de marca, los coches lujosos, etc. es muy llamativa entre estos chicos y aunque está presente también entre los jóvenes en Marruecos, lo significativo aquí es

44. «[Entrevistadora:] ¿Tú cómo tratarías a un hijo así [como él mismo]? [Entrevistado:] Pues bien..., normal... No le dejaría lo que hago yo, o sea, ni fumar..., o sea, yo, yo no voy a dejar fumar..., pues a ver si estudia, lo que yo no he hecho..., y esas cosas» (E4).

"Mi abuela, cuando me pillaron en Marruecos fumando, me dijo que "por favor, hijo", que no haga nada, que estudie mejor, que es mejor para mí. Y, bueno, mi madre le ha dicho que he vuelto a fumar: "Mira, si vuelve a fumar, de tanto que le quiero, que no vuelva a hablar conmigo nunca hasta que deja de fumar”. Y yo: “ㅌh, joder, qué dices hombre...!!. Mi abuela es que es mi abuela; mi abuela ya... [está emocionado] lo que diga es lo que hay que hacer» (E9). 
el recurso a medios ilegales (trapicheo, pequeños hurtos, venta de falsificaciones traídas de Marruecos, etc.) para hacerla posible, y ello entre quienes están más o menos sujetos al control familiar. Se manifiesta aquí con claridad la «disociación entre las aspiraciones culturales prescritas y los caminos socialmente estructurales para llegar a dichas aspiraciones», la anomia (Merton, 1965: 143).

En el ámbito de las conductas anómicas, incluimos también el consumo de drogas — sobre todo hachís y marihuana-y de alcohol, las frecuentes peleas grupales o individuales, pequeños hurtos y la indisciplina en el seno del aula. Todo esto es más evidente entre los chicos de familias desestructuradas (no me refiero a la forma, sino al cumplimiento de sus funciones por parte de los progenitores), pero no suele ocurrir entre las chicas en similares circunstancias.

La anomia no significa desconocimiento de las normas. Esto se manifiesta en el sentimiento de culpabilidad claro en algunas entrevistas, en la referencia a la propia conducta como "cosas malas", en la conciencia del disgusto que saber de ella ocasionaría a la familia e incluso en la evitación de la misma cuando se está en Marruecos o, al menos, su limitación u ocultamiento ${ }^{45}$.

\section{Conclusión}

El estudio Husband sobre la negociación de identidad entre las comunidades iraní y pakistaní en Reino Unido pone de manifiesto la "compleja interrelación entre la identidad étnica y la relevancia y trascendencia de la afiliación religiosa, así como claras evidencias de la importancia del sexo y la generación» (2001: 98). Por lo que a nuestro estudio se refiere, tales conclusiones se corroboran en lo relativo a la afiliación religiosa y también al sexo: si la identidad étnica es la norma en todo caso, los componentes que Phinney (1991) refiere — vide supra - muestran un peso desigual entre ellos y ellas. La diferencia más clara tiene que ver con las "conductas y las prácticas étnicas». Incluso considerando el referido patrón cultural de mayor permisividad hacia los varones, su conducta muestra con relativa frecuencia que dicho patrón es ampliamente superado. La causa fundamental ha sido ya apuntada: el papel de salvaguarda frente al riesgo de anomia de la familia y del entorno social y del islam se debilita tras la migración. En la confrontación entre la situación vital que los adolescentes y las adolescentes de origen marroquí encaran, se manifiesta claramente el dilema entre libertad y seguridad que atraviesa las sociedades actuales y que Bauman (2001) expone con precisión: este dilema se precipita entre

45. En términos de Merton: «Parece improbable que las normas culturales, una vez interiorizadas, sean completamente eliminadas. Cualquier residuo que persista producirá tensiones de la personalidad y conflictos, con cierto grado de ambivalencia [...] Sentimientos de culpabilidad, una sensación de pecado, dolores de conciencia, son expresiones diferentes para denominar la tensión no aliviada» (1965: 144, nota a pie número 7). 
comunidades tradicionalmente inmunizadas como la marroquí, a raíz del cambio vital que fuerza la emigración. Dice también Bauman que «la "individualización" consiste en convertir la "identidad" humana de algo dado en una "tarea", y cargar a los actores con la responsabilidad de realizar esta tarea y con las consecuencias (también los efectos secundarios) de su realización» (2001: 166). Es evidente que esto ocurre en las sociedades modernas occidentales y que también el cambio de contexto tras la migración puede convertir en tarea lo que antes venía dado. Creo también, sin embargo, que, entre la población inmigrante marroquí el peso de lo comunitario en la construcción individual de la identidad se mantiene y que los discursos recogidos entre los adolescentes no dejan, por lo general, entrever dolor por tal constricción, si acaso por la falta de ella.

\section{Referencias bibliográficas}

Aranguren, J.L. (1993). «El Yo, el sí mismo, el otro y el Otro». Revista de Occidente, 140.

AZIRA, M.; SENTHIKUMARAN, A. y JA'FAR, Z. (2007). Living together apart. [www.policyexhange.org.uk]

BaUman, Z. (2001). La sociedad individualizada. Madrid: Cátedra.

- (2003). Comunidad: En busca de seguridad en un mundo hostil. Madrid: Siglo XXI. BOURDIEU, P. (1999). La miseria del mundo. Madrid: Akal.

Coser, L.A. (1978). Las instituciones voraces. México: Fondo de Cultura Económica. ERIKSON, E. (1980). Identidad: Juventud y crisis. Madrid: Taurus.

GIDDENS, A. (2000). Un mundo desbocado. Madrid: Taurus.

Goffman, E. (1970). Estigma, la identidad deteriorada. Buenos Aires: Amorrortu.

Hassini, M. (1997). L'école: une chance pour les filles de parents maghrébins. París: L'Harmattan.

Husband, C. (2001). «La negociación de identidades en el contexto de la diáspora: la población pakistaní en Bradford». En: TuRTON, D. y GonZÁlez FerReras, J. (eds.). Identidades culturales y minorías étnicas en Europa. Bilbao: Universidad de Deusto, 93-108.

LAMO DE EsPINOSA, E. (ed.) (1995). Culturas, estados, ciudadanos. Una aproximación al multiculturalismo en Europa. Madrid: Alianza.

MCADAMS, D.P. (1989). «Desarrollo de la identidad narrativa». En: Buss, D. y CANTOR, M.N. (eds.). Personality Psychology: Recent trends and emerging directions. Nueva York: Springer. El capítulo de McAdams, «The Development of a Narrative Identity», aquí citado, ha sido traducido por Consuelo Salazar Chávez, mimeo.

Merton, R.K. (1965). Teoría y estructura sociales. México: Fondo de Cultura Económica.

NANDA, S. (1987). Antropología cultural: adaptaciones sociales. México: Grupo Editorial Iberoamérica.

PARK, R.E. (1999). La ciudad y otros ensayos de ecología urbana. Estudio preliminar y traducción de E. Martínez. Barcelona: Ediciones del Serbal.

Pew Research Center (2006). Muslims in Europe: economic worries top concernes about religious and cultural identity. [www.pewglobal.org]

PHInNEY, J.S. (1991). «Ethnic Identity and selfsteem: a review and integration». Hispanic Journal of Behavioral Sciencies, 12 (2), 193-208. 
RAMíREZ, A. (1998). Migraciones, género e islam: Mujeres marroquies en España. Madrid: AECI.

ReVILla, J.C. (1998). La identidad personal de los jóvenes: pluralidad y autenticidad. Madrid: Entinema.

SMITH, A. (1991). La identidad nacional. Madrid: Trama, 1997.

Solé, C. y Parella, S. (2005). "Intereses e identidad». Praxis Sociológica, 9, 9-22. TERRÉN, E. (2007). «Adolescencia, inmigración e identidad». En: CACHÓN, L. y SALAS, A.M. Juventud e inmigración. Desafíos para la participación y para la integración. Tenerife: Gobierno de Canarias.

VEREDAS, S. (1999). "Procesos de construcción de la identidad entre la población inmigrante». Papers: Revista de Sociología, 57, 113-129. 